\title{
The Effect of Leadership Style and Compensation on the Work Performance of Merangin District Office Employees, Jambi: The Role of Work Motivation
}

\author{
Nalim Nalim ${ }^{1}$, Siswoyo Haryono ${ }^{2}$, Murniady Muchran ${ }^{3}$ \\ ${ }^{1}$ The Regent of Merangin, Management, Faculty of Economics, Universitas Persada Indonesia, Jakarta \\ 2 Doctor of Management, Postgraduate Program, Universitas Muhammadiyah Yogyakarta \\ ${ }^{3}$ Doctor of Management, Postgraduate Program, Universitas Muhammadiyah Yogyakarta \\ Corresponding Author: murniadymuchran@gmail.com
}

\section{Article Info}

Keyword:

Leadership Style;

Compensation;

Work Motivation;

Performance.

\section{Kata Kunci:}

Gaya Kepemimpinan;

Kompensasi;

Motivasi Kerja;

Kinerja.

\begin{abstract}
The purpose of this study was to examine the effect of leadership style and compensation on work motivation and its implications for the performance of the staff of the Merangin Regency Secretariat, Jambi, Indonesia. Research on 245 respondents from the Merangin Regency Secretariat staff, Jambi, Indonesia. The research method uses descriptive research and survey methods. The analysis model uses SEM (Structural Equation Modeling) analysis. The results showed: (1) There was a positive and significant influence of leadership style on work motivation, (2) There was a positive and significant effect of compensation on work motivation, (3) There was a positive and significant influence of leadership style on employee performance. (4) There is no effect of compensation on employee performance, (5) There is a positive and significant effect of work motivation on employee performance. From the results of the analysis of direct and indirect effects, motivation in this study is an intervening variable. The work motivation variable is intervening, especially for the compensation variable. It is recommended to the Merangin Regency Secretariat, Jambi, to improve employee performance, it is necessary to pay attention to the variables of leadership style, compensation, and work motivation.
\end{abstract}

\begin{abstract}
Abstrak: Tujuan penelitian adalah untuk menguji pengaruh gaya kepemimpinan dan kompensasi terhadap motivasi kerja dan implikasinya terhadap kinerja staf Sekretariat Kabupaten Merangin, Jambi, Indonesia. Penelitian terhadap 245 responden karyawan Sekretariat Kabupaten Merangin, Jambi, Indonesia. Metode penelitian menggunakan metode penelitian deskriptif dan survei. Model analisis menggunakan analisis SEM (Structural Equation Modeling). Hasil penelitian menunjukkan: (1) ada pengaruh positif dan signifikan gaya kepemimpinan terhadap motivasi kerja, (2) ada pengaruh positif dan signifikan kompensasi terhadap motivasi kerja, (3) ada pengaruh positif dan signifikan gaya kepemimpinan pada kinerja karyawan. (4) tidak ada pengaruh kompensasi terhadap kinerja karyawan, (5) terdapat pengaruh positif dan signifikan motivasi kerja terhadap kinerja karyawan. Dari hasil analisis efek langsung dan tidak langsung, dapat disimpulkan bahwa motivasi kerja dalam penelitian ini adalah variabel intervening. Variabel motivasi kerja adalah intervening, terutama untuk variabel kompensasi. Direkomendasikan kepada Sekretariat Kabupaten Merangin, Jambi, untuk meningkatkan kinerja karyawan, perlu memperhatikan variabel gaya kepemimpinan, kompensasi, dan motivasi kerja.
\end{abstract}




\section{INTRODUCTION}

One of the crucial agendas in developing the government is creating a clean and authoritative government. Important aspects related to efforts to realize good governance are openness, accountability, effectiveness, efficiency, upholding the rule of law, and increasing opportunities for public participation that can ensure the duties and functions of government and development are smooth, harmonious, and integrated. Type of leadership has a major positive impact on the efficiency of the employees. Work motivation has a significant positive effect on the performance of the employees. Job discipline has an significant positive impact on the output of employees (Azzahrati, 2018). Achieving an organization's objectives requires human resources as a manager of the system. Of course, in order for this program to work, its management needs to pay attention to many important aspects such as leadership , motivation, work climate, efficiency and other (Potu, 2013). Leadership and organizational culture have a very close relationship, because each leader has a different style of leadership that will ultimately form a culture of organization (Fahmi et al., 2018). The various policy steps aimed at institutional change, and effective monitoring and inspection systems are urgently needed. Some factors affect the success or failure of the development process in this area, including the condition of government officials. Bureaucracy is the backbone in running the wheels of government, development program factors $s$ and society and power. Thus, the reform period gave meaning to the birth of revolutionary leaders with their authority as autonomous regions, so the government bureaucracy continuously revamped to support the system of performance appliance management (Ramli, 2017). The main task of the bureaucracy is to provide optimal services to the community and to do everything that enhances the implementation of government, development, and community tasks by achieving the targets set. For this purpose, the realization of good governance and clean governance is a must (Siswoyo Haryono \& Arafat, 2017).

Many problems in the bureaucracy, especially in implementing Good Governance. These problems include recruitment systems, career paths, promotions and mutations, clarity of basic tasks and functions, quality of human resources, low performance, the orientation of behavioral and cultural values that do not value achievement, lack of discipline, well-being, not implementing rewards and punishment, wasteful and slow bureaucracy. Luthans (2013: 175) defines transformational leadership as a form of leadership in which people engage with others and create relationships in leaders and followers that increase motivation and morals (Bagus et al., 2017). All these problems make it difficult for the bureaucracy to carry out its duties, so that bureaucratic reform is a must, especially to restore the duties and functions of the bureaucracy as a professional, neutral, legal and modern organization. Human resources (HR) is an essential role for an organization in achieving its goals. Therefore, in an organization, ethical leadership and excellent HR performance are needed. Employees who perform work well would get better compensation. The leader will transfer certain values, such as group emphasis, support from people or employees, risk tolerance, remuneration criteria and so on, through the leadership of a person leader (Ismail, 2017). As well as of leadership, this purpose to successful leaders must have versatile habits or styles of leadership and be able to recognize the situation they face, and use leadership models suitable to the situation they face (Hakim et al., 2017).

Leadership is not "one size fits all"; often, a manager must adjust their style to suit a particular situation or group, and this is why it is necessary to understand the various leadership styles thoroughly; after all, the more approaches that managers are familiar with, the more tools they can use to lead effectively (A.Murray, 2013). Motivation is the most significant element for all private or public zones. Motivation plays an essential role in the achievement of any organization. Motivation requirements come from the word motive. Armstrong defines compensation as something that is received by an employee, both financial and non-monetary rewards for employee contributions to the organization. Compensation management is a critical activity to make employees quite satisfied with their work (Armstrong, 2017).

The most significant driving force for performance is the responsibility, while additional benefits are the second significant factor. HR management can use various plans or factors to simulate employees but must remember that different motivational factors or plans will have 
different motivational effects on different employees (Ghaffari et al., 2017). A manager must consider various incentive plans to influence employees in different ways and positions, according to the situation, needs, and goals of individual employees (Haryono \& Arafat, Yasir, 2017). In the motivational plans, HR management must understand the differences in values, needs, tasks, and motivational levels of employee satisfaction in terms of improving work performance and productivity. Lan Study by (Ali \& Ahmad, 2014), motivation plays a vital role in employee performance and job satisfaction in the IT Park (home software) sector of Peshawar, Pakistan. Research by (Darma \& Supriyanto, 2017) The results show that compensation affects employee satisfaction and employee performance at PT. Indonesian Telecommunications. While a study by (Nawoseing'ollan \& Roussel, 2017) revealed that there is no perfect leadership style. According to this research, the following leadership style affects the work performance of women; affiliate leadership, an authoritative leadership style of employee performance and it was concluded that the two leadership styles influence the style of local government employees in Turkana District and therefore both styles must be adopted and not each style alone.

Motivasi is a set of attitudes and values that influence individuals to achieve certain things with individual goals. Attitudes and values give strength to encourage individuals to behave in achieving their goals. Encouragement consists of two components, namely the direction of behavior that is working to achieve goals, and the strength of behavior that is how strong individual efforts at work (Mathis, L., 2016). While the leadership is an attempt to influence many people through communication to achieve the intended objectives, how it affects many people through instructions or orders (Hersey, P., Kenneth H, Blanchard, and Dewey, 2012) style of leadership is an important aspect to achieve and improve the success of leadership d nature of an organization. G aya leadership is the norm of behavior that is used by a person to influence the behavior of others or subordinates (Geier, 2016). Leadership style is a set of characteristics used by leaders to influence subordinates so that organizational goals achieved or can also be said leadership style is a pattern of behavior and strategies that are liked and often applied by a leader (Gencer \& Samur, 2016). Some previous studies that discussed the same issues as in this study, including conducted by (Nawoseing'ollan \& Roussel, 2017; Razak et al., 2018; Musty, 2015; Syafii et al., 2015) wherein general the results of their study said that leadership style affects employee work motivation. Based on the theories and opinions of experts and relevant previous research, there is an influence of leadership style on work motivation. So based on the description of the theory and previous research above $t$ can be assumed that there is an influence of leadership style on work motivation.

H1: There is an influence of leadership style on work motivation

Work Compensation is everything received by the employee as a reward for their contribution to the company (Ardana, 2012). Furthermore, Williamson (2012) defines compensation as any form of payment given to employees arising from their work. Compensation is a factor that can increase employee motivation to create a spirit for employees to resolve any responsibility given by the company. Therefore it is essential for companies to pay attention to a compensation system that is applied to maintain and improve employee motivation (Ganta, 2014) In a study conducted by (Imran et al., 2016; Ketut et al., 2018; Maria, 2019; Papilaya et al., 2019) the results of their research indicate that the compensation variable influences work motivation. Based on the theories and opinions of experts and relevant previous research, that there is a compensation effect on work motivation.

\section{H2: There is a compensation effect on work motivation}

Leadership style is a behavior pattern in the form of the words and actions of a leader is perceived by others (Hersey, P., Kenneth H, Blanchard, and Dewey, 2012). A leader has the characteristics, habits, temperament, character, and personality is unique, so the behavior and style that distinguish themselves from others. His style or lifestyle will color his behavior and type of leadership. K low employee not only because of the employee's fault, but there is the possibility of leadership that was less precise (Yukl, 2018). Performance is the result of work that is closely related to the goals of the Organization and consumers contributing to the economy 
(Armstrong, 2017) Based on previous research conducted by (Asrar-ul-Haq \& Kuchinke, 2016; Chou et al., 2013; Creţu, 2015; Razak et al., 2018; Wahyu, 2019), the findings of this study indicate that leadership style has a good effect on improving performance. Based on theories and opinions of experts and previous research that is relevant, are suspected influence of leadership style on performance.

H3: There is an influence of leadership style on performance

Compensation under (Armstrong, 2017) consists of two types: (1) financial compensation and (1) non-financial compensation. Financial compensation consists of direct compensation, such as (a) basic salary, b) decent salary, salary, bonus, commission, profit sharing, profit sharing, and stock distribution and (c) different payments. Indirect compensation ( 1 ) benefits programs, namely health insurance, life insurance, pension, and labor insurance, ( 2 ) payment outside working hours as holiday programs, annual leave and maternity leave, ( 3 ) the vehicle, office space, and parking lot. Non- financial compensation can e divided into ( 1 ) work with tasks, challenges, responsibilities, recognition and an overwhelming sense of achievement and ( 2 ) work environment, such as good policy, competent supervisors, happy work atmosphere, and a pleasant work environment comfortable to live. Sinambela argues performance is the capacity of and efforts of a person in determining the ability of (Sinambela, 2016). The force is reinforced by the motives that emerge from the individual himself (Cooley, Van E; Shen, 2010; Rahabav, 2014). According to the results of previous studies conducted by (Darma \& Supriyanto, 2017; Hameed, A., Ramzan, M., \& Zubair, n.d.; Ketut et al., 2018; Papilaya et al., 2019), the results of their study showed that the compensation variable would influence performance improvement. Therefore, based on the theory and the expert opinion and previous research that is relevant, $d$ idea there is the influence of compensation on performance.

H4: There is an effect of compensation on performance

According to Davis and McClelland, the factors that influence the achievement of performance are the ability and motivation factors, and according to McClelland, there is a positive relationship between high achievement motives and performance achievement (Davis, 2010; McClelland, 1987). The motive for high achievers is an encouragement to employees to carry out an activity or task as best they can to achieve performance with appreciation. Motivation arises because of two factors: (1) internal factors that arise from within oneself, (2) external factors come from outside (Armstrong, 2017) (Armstrong, 2017). Motivation is a process that explains the intensity, direction, and perseverance of someone in trying to achieve their goals (Wukir, 2013). Motives are needs, desires, impulses. Positive motivational philosophies and practices can improve productivity and quality of work. According to the results of research conducted by Pinar, it as found that extrinsic and intrinsic motivation is an impact on employee performance (Pinar, 2011). Motivation is a top priority for managers. Managers must develop organizational strategies to motivate employees-the primary goal of organizational management to improve organizational performance (Zlate \& Cucui, 2015). Research by (Ali Amjad, 2017; Ghaffari et al., 2017; Razak et al., 2018) indicates that there is a positive influence between work motivation on performance. Based on the theories and opinions of experts and relevant previous research, there can be three effects of work motivation on performance.

H5: There is an influence of work motivation on performance

\section{RESEARCH METHOD}

The subjects in this study were employees of the Merangin Regency Secretariat, Jambi. While the object of this research is Merangin Regency Secretariat, Jambi, Indonesia. Data were collected through questionnaire distribution and face-to-face by researchers. The sample of this study was 245 employees of the Merangin Regency Secretariat, Jambi, Indonesia. This study consists of leadership style variables, compensation, work motivation, and performance measured by instruments with a Likert scale of $1-5$. The scale represents a rating from 'strongly 
disagree' to 'strongly agree.' The measurement of leadership style is with eight questions according to the opinion of Gary A Yukl (Yukl, 2018). The compensation variable consists of 12 questions based on the definition of Lujan P Sinambela (Sinambela, 2016). The work motivation variable consists of 16 questions developed based on AH Maslow's opinion (Maslow, 2013), while the employee performance consists of 13 questions developed from the opinion of Dick Grote (Grote, 201onsists of 1).

This study uses quantitative research by developing valid and reliable research instruments on research variables, including leadership style variables and compensation for work motivation and their implications for the performance of employees of the Merangin Regency Secretariat, Jambi, Indonesia. The research design uses Structural Equation Modeling (S. Haryono, 2017). The statistical tool used to analyze data and answer hypotheses is the Lisrel version 8.8 program. The researcher employed the goodness of fit test technique to test the indicators' validity and reliability. The measurement model will apply convergent validity to test whether the indicator is valid or not. This study used the Maximum Likelihood Estimation (MLE) technique. The assessment of questionnaire items was carried out by the Confirmatory Factor Analysis (CFA) to examine the relationship between constructs and indicators based on the theory developed. This method also employed Cronbach's Alpha to test construction reliability. The CFA test results shown in Table.1 show that the value for loading factors (full model fit) in each question item is $>0.5$, which can all question items are valid. Meanwhile, Table. 2 shows that the value of Construct Reliability is $\geq 0.7$, and Variance Extracted is $\geq 0.5$ for each construct, which explains that all constructs are reliable. The CFA test results concluded that all indicators are suitable to measure variables and analyze research data.

Table.1 Validity Test Results Based on Full Model Fit

\begin{tabular}{cc}
\hline INDICATOR & ESTIMATE \\
\hline LS02 & 0.90 \\
LS03 & 0.92 \\
LS04 & 0.86 \\
LS07 & 0.86 \\
LS08 & 0.80 \\
CS07 & 0.75 \\
CS08 & 0.90 \\
CS09 & 0.79 \\
CS10 & 0.83 \\
CS11 & 0.79 \\
MV02 & 0.86 \\
MV03 & 0.85 \\
MV08 & 0.66 \\
MV12 & 0.94 \\
MV13 & 0.85 \\
MV14 & 0.87 \\
PF02 & 0.81 \\
PF03 & 0.83 \\
PF04 & 0.87 \\
PF06 & 0.81 \\
PF07 & 0.87 \\
PF08 & 0.84 \\
PF09 & 0.80 \\
PF11 & 0.84 \\
PF13 & 0.75 \\
\hline
\end{tabular}


Table.2 Reliability Test Results Based on the Fit Model

\begin{tabular}{lccc}
\multicolumn{1}{c}{ Variables } & $\begin{array}{c}\text { Construct } \\
\text { Relia ability } \geq \mathbf{0 . 7}\end{array}$ & $\begin{array}{c}\text { Variance } \\
\text { Extracted } \geq \mathbf{0 . 5}\end{array}$ & Result \\
\hline Leadership Style (LS) & 0.97 & 0.93 & Reliable \\
Compensation (CS) & 0.82 & 0.70 & Reliable \\
Motivation (MV) & 0.75 & 0.54 & Reliable \\
Performance (PF) & 0.98 & 0.94 & Reliable \\
\hline
\end{tabular}

\section{RESULT AND DISCUSSION}

Hypothesis testing in this research was analyzed using Structural Equation Modeling (SEM) of the second-order with Lisrel version 8.8. Figure.1 shows Complete SEM test results. e 1. Meanwhile, Table.3 explains the assumptions of test results in SEM development. Confirmation of the model fit test on the complete model that meets the goodness of fit criteria. The structural model is used to draw a model of research causality with structural relationships. Goodness of fit test results are as follows: Chi-Square $=282.38$, probability $=0.1, \mathrm{GFI}=0.92$, $\mathrm{AGFI}=0.89, \mathrm{CFI}=1.00, \mathrm{TLI}=1.00, \mathrm{IFI}=0,97$ and $\mathrm{RMSEA}=0.02$. All research criteria have met the required cut-off value. This result shows that the research model is suitable and meets the standard criteria for analyzing and testing the proposed hypothesis.

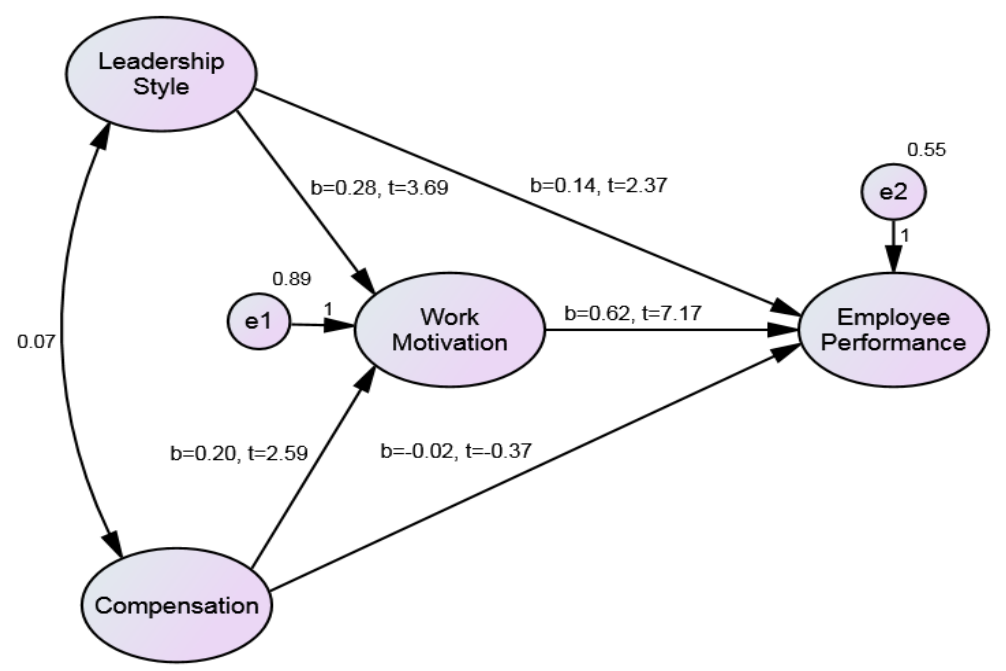

Figure.1

Effect of Leadership Style and Compensation on Work Motivation and Its Implications on the Performance of Merangin Regency Secretariat staff, Jambi, Indonesia

Table.3 Path Coefficients

\begin{tabular}{|c|c|c|c|c|}
\hline Hypothesis & Structural Path & $\begin{array}{c}\text { Standardized } \\
\text { Path } \\
\text { Coefficients }\end{array}$ & t-Value & Results \\
\hline $\mathrm{H}_{1}$ & Leadership Style --> Work Motivation & 0.28 & 3.69 & Significant \\
\hline $\mathrm{H}_{2}$ & Compensation --> Work Motivation & 0.20 & 2.59 & Significant \\
\hline $\mathrm{H}_{3}$ & $\begin{array}{l}\text { Leadership Style --> Employee } \\
\text { Performance }\end{array}$ & 0.14 & 2.37 & Significant \\
\hline $\mathrm{H}_{4}$ & $\begin{array}{l}\text { Compensation --> Employee } \\
\text { Performance }\end{array}$ & 0.02 & -0.37 & No-Significant \\
\hline $\mathrm{H}_{5}$ & $\begin{array}{l}\text { Work Motivation --> Employee } \\
\text { Performance }\end{array}$ & 0.62 & 7.17 & Significant \\
\hline
\end{tabular}


Based on testing hypothesis 1 , there is a positive and significant influence of leadership style on work motivation, based on ( $t$ arithmetic $=3.69>1.96)$. These results are consistent with research conducted by (Razak, 2018), (NawoseIng'ollan, 2017), (Musty, 2015), and (Syafi'i, 2015). The results of their study show that leadership style influences work motivation. Based on the findings of testing the hypothesis and previous research, leadership style is an essential aspect of achieving organizational goals. Leadership style is a set of characteristics used by leaders to influence subordinates so to achieve organizational goals.e achieved, or it can also be aid that the leadership style is a pattern of behavior and strategies that are preferred and often applied by a leader.

Based on testing hypothesis 2, it s concluded that there is an effect of compensation on work motivation, based on ( $t$ arithmetic $=2.59>1.96)$. The results of this study are consistent with previous studies by (Maria 2019), (Papilaya, 2019), (Rasheed, 2016), and (Sudiardhita, 2018), where their results showed that variable compensation affected work motivation. Based on the results of hypothesis testing and previous research, it can e said that the compensation is one of the factors that can increase employee motivation and also be able to create enthusiasm for employees in completing any responsibilities. Therefore, companies need to pay attention to a compensation system that is applied to maintain and enhance employee work motivation the employee.

Based on testing hypothesis 3 , it is concluded that there is an influence of leadership style on performance, with ( $\mathrm{t}$ arithmetic $=2.37>1.96)$. These results are consistent with research conducted by (Cretu, 2015), (Musty, 2015), (Asrar, 2016), (Razak, 2018), (Chou, 2013), and (Wahyu, 2019), their research findings indicate that leadership has a good effect on improving performance. Based on the results of testing hypotheses and previous research, it can e said that low performance is not only due to the mistakes of the employees themselves, but there is a possibility that the leadership style of the leader is inappropriate.

Based on testing hypothesis 4, it s concluded that there is no effect of compensation on performance, based on ( $\mathrm{t}$ arithmetic $=-0.37<1.96)$. The results of this study are in line with previous studies conducted by (Papilaya, 2019). The findings of this study indicate that compensation does not show a direct effect on performance, but must first go through the variables of transparency and motivation. Based on the results of hypothesis testing and previous research, that one way to motivate employees is through compensation. Likewise, Grote states that compensation has a positive effect on performance, but through motivation as an intervening variable. Satisfaction with compensation provided by companies in the form of salaries, bonus allowances, and a variety of adequate facilities will foster employee motivation because they feel valued and supported at work. High motivation makes employees more focused and attentive to efforts to achieve the excellent work that the company expects from them (Grote, 2011).

Based on testing hypothesis 5, it s concluded that there is an influence of work motivation on performance, based on ( $\mathrm{t}$ arithmetic $=7.17>1.96)$. These results are consistent with research conducted by (Razak 2018), (Ali Amjad, 2017) (Ghaffari, 2017) in which the results of the study showed that motivation affects performance. Based on the results of testing hypotheses and previous research, dit s expected that the company or organization can develop organizational strategies to motivate employees, so this becomes the primary goal of organizational management to improve organizational performance.

\section{CONCLUSION}

Based on testing the research hypothesis, it as found that the leadership style and work motivation partially had a positive and significant effect on performance. As for the compensation variable, it does not directly affect performance but can through work motivation first. Based on the results of the analysis and conclusions from this study also obtained some empirical evidence can e used as input for a staff of the Secretariat of Merangin Regency, Jambi, Indonesia, to improve work motivation and employee performance. Leadership and compensation partly influence work motivation. This view implies that motivating employees through various efforts, including the application of appropriate leadership styles and also 
compensating employees. Based on direct and indirect effects, the compensation variable does not have a direct influence on performance but must go through the work motivation variable first. So to improve employee performance to be more optimal, what must e is to motivate employees through the application of appropriate leadership styles and also providing compensation for employees.

\section{ACKNOWLEDGMENT}

The author realizes that there are still many shortcomings in this study, so the authors expect input and suggestions to improve this research in the future. The authors thank those who have helped and contributed to the realization of writing this research.

\section{REFERENCE}

A.Murray. (2013). The Wall Street Journal Guide To Management: Lasting Lessons From The Best Leadership Minds Of Our Time. Harper Collins Publisher.

Ali, A., \& Ahmad, K. (2014). The impact of socio-economic factors on life expectancy in Sultanate of Oman : An empirical analysis. Middle-East Journal of Scientific Research, 22(2), 218-224. https://doi.org/10.5829/idosi.mejsr.2014.22.02.21847

Ardana, a. I. . (2012). Manajemen Sumber Daya Manusia. Graha Ilmu.

Armstrong, M. (2017). Armstrong's Handbook of Performance Management: An Evidence-Based Guide to Delivering High-Performance. Kogan Page Publishers.

Asrar-ul-Haq, M., \& Kuchinke, K. P. (2016). Impact of leadership styles on employees' attitude towards their leader and performance: Empirical evidence from Pakistani banks. Future Business Journal, 2(1), 54-64. https://doi.org/10.1016/j.fbj.2016.05.002

Azzahrati, A. (2018). Pengaruh Gaya Kepemimpinan Dan Disiplin Kerja Terhadap Kinerja Karyawan. At-Tadbir: Jurnal Ilmiah Manajemen, 2(1). https://doi.org/10.31602/atd.v2i1.1189

Bagus, M., Subawa, A., \& Suwandana, I. G. M. (2017). Organizational Citizenship Behavior. 6(9), 4772-4799.

Chou, H. W., Lin, Y. H., Chang, H. H., \& Chuang, W. W. (2013). Transformational leadership and team performance: The mediating roles of cognitive trust and collective efficacy. SAGE Open, 3(3), 1-10. https://doi.org/10.1177/2158244013497027

Cooley, Van E; Shen, J. (2010). School accountability and professional job responsibilities: A perspective from secondary principals. National Association of Secondary School Principals. NASSP Bulletin;

Creţu, D. (2015). Identification of Leadership Styles in The Pre-University Educational System. Case Study. Procedia - Social and Behavioral Sciences, 186, 535-543. https://doi.org/10.1016/j.sbspro.2015.04.058

Darma, P. S., \& Supriyanto, A. S. (2017). the Effect of Compensation on Satisfaction and Employee Performance. Management and Economics Journal (MEC-J), 1(1), 66. https://doi.org/10.18860/mec-j.v1i1.4524

Davis, R. (2010). The intangibles of leadership: The 10 qualities of superior executive performance. John Wiley \& Sons.

Fahmi, M., Agung, S., \& Rachmatullaily, R. (2018). Employee Management Style and $\begin{array}{llll}\text { Organizational } \quad \text { Environment. } & \text { Inovator, }\end{array}$ https://doi.org/10.32832/inovator.v7i1.1462

Ganta, V. C. (2014). Motivation in the Workplace To Improve the Employee Performance Vinay Chaitanya Ganta. International Journal of Engineering Technology Management and Applied Sciences Www.Ijetmas.Com, 2(6), 2349-4476. http://www.ijetmas.com/admin/resources/project/paper/f201411201416479373.pdf

Geier, M. T. (2016). Leadership in Extreme Contexts: Transformational Leadership, Performance Beyond Expectations? Journal of Leadership and Organizational Studies, 23(3), 234-247. https://doi.org/10.1177/1548051815627359

Gençer, M. S., \& Samur, Y. (2016). Leadership Styles and Technology: Leadership Competency Level of Educational Leaders. Procedia - Social and Behavioral Sciences, 229, 226-233. 
https://doi.org/10.1016/j.sbspro.2016.07.132

Ghaffari, S., Burgoyne, J., Ghaffari, S., Shah, I. M., Burgoyne, J., Salah, J., \& Aziz, S. (2017). Investigating the Mediation Role of Respect for Employees on the Relationship between Participative Leadership and Job Satisfaction : A Case Study at Universiti Teknologi Malaysia Research Paper: Investigating the Mediation Role of Respect for Employees . 11(March 2019).

Güngör, P. (2011). The relationship between reward management system and employee performance with the mediating role of motivation: A quantitative study on global banks. Procedia - Social and Behavioral Sciences, 24, 1510-1520. https://doi.org/10.1016/j.sbspro.2011.09.029

Hakim, L., Asmony, T., \& Inapty, B. A. (2017). Pengaruh Komitmen Organisasional, Sistem Pengendalian Intern Pemerintah, dan Gaya Kepemimpinan Terhadap Kinerja Manajerial (Survey Pada SKPD Sumbawa Dan Sumbawa Barat). Journal of Auditing, Finance, and Forensic Accounting, 4(2), 67. https://doi.org/10.21107/jaffa.v4i2.2781

Hameed, A., Ramzan, M., \& Zubair, H. M. K. (n.d.). Impact of compensation on employee performance (empirical evidence from banking sector of Pakistan). International Journal of Business and Social Science, 5(2).

Haryono, S. (2017). Metode SEM untuk Penelitian Manajemen AMOS Lisrel PLS. Luxima Metro Media.

Haryono, Siswoyo, \& Arafat, Y. (2017). Effects of Organizational Culture and Work Motivation on Job Performance Among the Private Universities' Full-time Faculties in South Sumatera Province. 123(5), 3654-3654. https://doi.org/10.1121/1.2934955

Hersey, P., Kenneth H, Blanchard, and Dewey, Ej. (2012). Management of Organizational Behavior (10th Edition) In 10 (Ed.): Pearson. Pearson.

Imran, R. M., Afzal, H. A., Usama, A., \& Din, A. A. ud. (2016). Factors affecting teachers' motivation: An HRM challenge for public sector higher educational institutions of Pakistan (HEIs). International Journal of Educational Management, 30(1), 101-114. https://doi.org/10.1108/IJEM-04-2014-0057

Ismail, I. (2017). Pengaruh Budaya Organisasi Terhadap Kepemimpinan Dan Kinerja Karyawan Pemerintah Kabupaten-Kabupaten Di Madura. EKUITAS (Jurnal Ekonomi Dan Keuangan), 12(1), 18. https://doi.org/10.24034/j25485024.y2008.v12.i1.2057

Ketut, S., Saparuddin, M., Budi, H., Herlitah, Tuty, S., \& Indah, N. S. (2018). The effect of compensation, motivation of employee and work satisfaction to employee performance PT. Bank XYZ (Persero) Tbk. Academy of Strategic Management Journal, 17(4), 1-14.

Maria, E. (2019). the Influence of Organizational Culture, Compensation and Interpersonal Communication in Employee Performance Through Work Motivation As Mediation. International Review of Management and Marketing, 9(5), 133-140. https://doi.org/10.32479/irmm.8615

Maslow, A. H. (2013). A Theory of Human Motivation. Start Publishing LLC.

Mathis, L., R. J. H. J. (2016). Human Resource Management. USA Cengage Learning.

McClelland, D. C. (1987). Human Motivation. Cambridge University Press.

Nawoseing'ollan, D., \& Roussel, J. (2017). Influence of Leadership Styles on Employees' Performance: A Study of Turkana County, Kenya. International Journal of Business and Social Science, 8(7), 82-98. www.ijbssnet.com

Papilaya, J., Tuakora, P., \& Rijal, M. (2019). Compensation, transparency, and motivation effects on the performance of junior high school teachers in Western Seram, Indonesia. International Journal of Instruction, 12(3), 439-458. https://doi.org/10.29333/iji.2019.12327a

Potu, A. (2013). Kepemimpinan, Motivasi, Dan Lingkungan Kerja Pengaruhnya Terhadap Kinerja Karyawan Pada Kanwil Ditjen Kekayaan Negara Suluttenggo Dan Maluku Utara Di Manado. Jurnal EMBA, 1(4), 1208-1218.

Rahabav, P. (2014). Kepemimpinan Kepala Sekolah Di Era Otonomi Pendidikan. PT. Kanisius.

Ramli, M. (2017). Kepemimpinan Inovatif Dalam Implementasi Kebijakan Strategis Pemerintah Kota Makassar. JPP (Jurnal Politik Profetik), 5(2), 168-184. 
https://doi.org/10.24252/JPP.V5I2.4343

Razak, A., Sarpan, S., \& Ramlan, R. (2018). Effect of leadership style, motivation and work discipline on employee performance in PT. ABC Makassar. International Review of Management and Marketing, 8(6), 67-71. https://doi.org/10.32479/irmm.7167

Sinambela, L. . (2016). Manajemen Sumber Daya Manusia: Membangun Tim Kerja yang Solid untuk Meningkatkan Kinerja. Bumi Aksara.

Syafii, L. I., Thoyib, A., Nimran, U., \& Djumahir. (2015). The Role of Corporate Culture and Employee Motivation as a Mediating Variable of Leadership Style Related with the Employee Performance (Studies in Perum Perhutani). Procedia - Social and Behavioral Sciences, 211, 1142-1147. https://doi.org/10.1016/j.sbspro.2015.11.152

Wahyu, N. D. (2019). The Effect of Perceived Organizational Support and Transformational Leadership Style on Employee Performance of Surabaya Municipality's Education Service Office. Russian Journal of Agricultural and Socio-Economic, 8, 92.

Wukir. (2013). Human Resource Management In A School Organization. Multi Presidio.

Yukl, G. (2018). Leadership in Organizations-A Book Review. Communication, Society and Media, 1(1), 81. https://doi.org/10.22158/csm.v1n1p81

Zlate, S., \& Cucui, G. (2015). Motivation and Performance in Higher Education. Procedia - Social and Behavioral Sciences, 180(November 2014), 468-476. https://doi.org/10.1016/j.sbspro.2015.02.146 